\title{
Implikacje długu publicznego dla polskiej gospodarki XXI wieku
}

\section{The implications of public debt for the Polish economy in XXI century}

Streszczenie: Dług publiczny, będący w dużej mierze konsekwencją deficytów budżetowych, jest zjawiskiem dosyć powszechnie występującym na świecie. Wiąże się to z odejściem w polityce budżetowej krajów od fundamentalnej zasady równowagi budżetowej.

Kryzys z 2008 roku potwierdził jednak, że dług publiczny może stanowić poważne zagrożenie bezpieczeństwa finansowego kraju, jego wzrostu i rozwoju gospodarczego. Wynika to z faktu, iż z długiem publicznym wiążą się koszty jego obsługi oraz szereg ryzyk, takich jak: ryzyko kredytowe, ryzyko płynności, ryzyko refinansowania itp.

Artykuł jest próbą odpowiedzi na następujące pytania badawcze:

- Co to jest deficyt budżetowy oraz jaka jest jego natura?

- Jakie są istota i źródła długu publicznego?

- Jakie są granice dhugu publicznego w teorii i praktyce gospodarczej?

- Kiedy i dlaczego dług publiczny staje się zagrożeniem dla gospodarki kraju?

- Jaka jest wielkość i struktura długu publicznego Polski?

- Na czym polega zarządzanie długiem publicznym?

Odpowiedzi uzyskane na powyższe pytania badawcze pozwolą zdiagnozować konsekwencje długu publicznego dla polskiej gospodarki oraz kierunki jego oddziaływania.

Abstract: Public debt, which is largely a consequence of budget deficit, is a quite common problem in the world. This is related to the discontinuation of balanced budget policy as the fundamental principle. However, the crisis of 2008 confirmed that budget deficit may cause a serious threat to financial security, economic growth and development of countries. This is due to the fact that public debt is associated with costs of servicing as well as a number of risks such as credit risk, risk of liquidity, risk of refinancing, etc.

The article is an attempt to answer following research question:

- What is a budget deficit and its nature?

- What is the essence and source of public debt?

- What are the limits of public debt in theory and economic practice?

- When and why public debt becomes a threat to the country's economy?

- What is the size and structure of the Polish public debt compared to selected European Union countries?

- What is the sense of debt management?

Responses to the questions above will help diagnose the consequences of public debt for Polish economy and the directions of its impact. 
Słowa kluczowe: deficyt budżetowy; dług publiczny; granice długu publicznego; koszty obsługi długu publicznego; ryzyko płynności; zarządzanie długiem publicznym

Keywords: budget deficit; costs of servicing public debt; public debt limit; public debt management; public debt; risk of liquidity

Otrzymano: 9 stycznia 2015

Received: 9 January 2015

Sugerowana cytacja / Suggested citation:

Pach, J. (2015). Implikacje długu publicznego dla polskiej gospodarki XXI wieku. Prace Komisji Geografii Przemystu Polskiego Towarzystwa Geograficznego, 29(1), 126-137.

\section{WSTĘP}

Dług publiczny, będący w dużej mierze konsekwencją deficytów budżetowych, jest zjawiskiem dość powszechnie występującym na świecie. Wiąże się to z odejściem w polityce budżetowej większości krajów od fundamentalnej zasady równowagi budżetowej, zakładającej równość wydatków budżetowych z dochodami budżetowymi, a zatem pełne ich pokrycie odpowiednimi dochodami budżetowymi. W konsekwencji budżet niezrównoważony z deficytem wymagającym zaciągania pożyczek stał się niemal standardem w polityce ekonomicznej krajów.

Kryzys z 2008 roku potwierdził jednak, że dług publiczny może stanowić poważne zagrożenie dla bezpieczeństwa finansowego kraju, jego wzrostu i rozwoju gospodarczego. Wynika to z faktu, iż z długiem publicznym wiążą się koszty jego obsługi oraz szereg ryzyk, takich jak: ryzyko kredytowe, ryzyko płynności, ryzyko refinansowania itp.

Artykuł jest próbą odpowiedzi na następujące pytania badawcze:

- Co to jest deficyt budżetowy oraz jaka jest jego natura i skutki?

- Jakie są istota i źródła długu publicznego?

- Jakie są granice deficytu i długu publicznego w teorii i praktyce gospodarczej?

- Jaka jest wielkość i struktura długu publicznego Polski na tle wybranych krajów Unii Europejskiej?

Odpowiedzi uzyskane na powyższe pytania badawcze pozwolą zdiagnozować konsekwencje długu publicznego dla polskiej gospodarki XXI wieku oraz wskazać kierunki jego oddziaływania.

\section{ŹRÓDŁA I NATURA DEFICYTU BUDŻETOWEGO}

W klasycznej teorii skarbowości zasada zrównoważonego budżetu należała do podstawowych reguł, natomiast dług publiczny dopuszczalny był jedynie w sytuacji konieczności ponoszenia wydatków związanych z prowadzeniem wojny (Dalton, 1948). Ponadto zgodnie z tzw. złotą regułą fiskalną zaciąganie długu publicznego było możliwe w celu finansowania zadań inwestycyjnych rokujących zwrot zainwestowanych środków, a nie bieżących wydatków (Kell, 2001). Współcześnie równowaga budżetowa oznaczająca pełne pokrycie wydatków budżetowych odpowiednimi dochodami jest zjawiskiem rzadkim 
w finansach publicznych. Na ogół występują odchylenia od równowagi w kierunku nadwyżki wydatków nad dochodami, co zwykło określać się mianem budżetów deficytowych. Natomiast sam deficyt budżetowy to nadwyżka wydatków nad dochodami w danym roku budżetowym.

Przyczyn deficytu budżetowego jest wiele, a do najważniejszych z nich zaliczyć należy:

- ekspansywną politykę fiskalną państwa, charakteryzującą się niskimi podatkami, a relatywnie wysokimi wydatkami,

- państwowy interwencjonizm gospodarczy, polegający na pobudzaniu popytu globalnego (konsumpcyjnego i inwestycyjnego), wzrostu zatrudnienia, inwestycji, nowych miejsc pracy itd., powodujący w efekcie wzrost wydatków publicznych,

- ponoszenie kosztów obsługi już istniejącego długu publicznego, obejmujących spłatę rat i odsetek od kredytów, wydatki na wykup obligacji i emisję nowych serii itp.,

- niższe od zaplanowanych dochody budżetowe, wynikające z przyczyn: ekonomicznych (pogorszenia się koniunktury gospodarczej), politycznych (embarga bądź sankcji gospodarczych) lub innych związanych z klęskami żywiołowymi, wojnami,

- budowę systemu finansów publicznych uwzględniającą nadmierne przepływy pomiędzy poszczególnymi funduszami, np. między budżetem państwa a funduszami emerytalnymi i ubezpieczeniowymi.

W każdym kraju deficyt budżetowy uwarunkowany jest także, poza wyżej wymienionymi, specyficznymi czynnikami oddziałującymi na stronę dochodów bądź wydatków publicznych. W krajach podlegających transformacji gospodarczej, reformujących swoje gospodarki, dużą rolę odgrywają wydatki na zmianę systemu gospodarczego, rozumianego jako zbiór elementów pozostających we wzajemnych relacjach i powiązaniach (Bertalanffy, 1984: 86). Powiązania te kształtują strukturę systemu gospodarczego. W wielu krajach zmiana ich systemu dokonuje się na drodze restrukturyzacji wybranych gałęzi i branż przemysłu oraz regionów o największych problemach gospodarczych, jak również przez rozwój infrastruktury technicznej.

W Polsce rok 1989 zapoczątkował proces przebudowy struktur gospodarczych - przechodzenie od systemu gospodarki centralnej do gospodarki rynkowej. W 1990 roku wszedł w życie program radykalnych reform systemowych, wciąż rozszerzanych i uzupełnianych aż do chwili obecnej. We wrześniu 1993 roku opracowano założenia długofalowej polityki przemysłowej na okres 10 lat oraz najważniejsze przedsięwzięcia i sposoby ich realizacji. Skoncentrowano się na restrukturyzacji wybranych gałęzi i branż przemysłu oraz regionów. Obecnie następują dalsze intensywne zmiany w strukturze produkcji poszczególnych gałęzi przemysłu. Mają one przede wszystkim na celu: ograniczenie udziału przemysłu ciężkiego w gospodarce, zwiększenie elastyczności w zakresie dostosowań podaży do zmieniającego się popytu, zwiększenie efektywności i konkurencyjności produkcji, przekształcenia własnościowe, zmianę kierunków geograficznych wymiany handlowej, wypracowanie proeksportowego profilu produkcji oraz wiele innych działań. Realizacja powyższych celów, jak również szeregu innych, spowodowała zwiększone wydatki budżetu państwa. 
Z kolei brak podjęcia głębokich zmian struktury gospodarki w Polsce mógłby zaowocować podobnymi skutkami jak w Rosji, której gospodarka opiera się na eksporcie gazu i ropy naftowej przynoszącym ponad 50\% przychodów rosyjskiego budżetu i 68\% przychodów z eksportu. W sytuacji spadku cen eksportowanych surowców dochody budżetu zmniejszają się. Obecnie mówi się o potrzebach zmian strukturalnych gospodarki rosyjskiej, o zastąpieniu towarów z importu przez rodzimą produkcję, ale takie strategie przynoszą efekty najwcześniej w średnim okresie (Standard..., 2014).

W świetle powyższego deficyt budżetowy wynikać może zarówno ze świadomej polityki gospodarczej rządu, jak i z żywiołowości procesów gospodarczych, które nie zawsze można przewidzieć w trakcie planowania budżetowego.

Należy podkreślić, iż deficyt budżetowy może mieć różne uwarunkowania i z tego względu wyróżnia się trzy jego rodzaje (Owsiak, 2013: 315):

- deficyt rzeczywisty, stanowiący faktyczną różnicę między wydatkami a dochodami budżetowymi w danym roku budżetowym; wielkość najczęściej prezentowana w ujęciach statystycznych (w mld zł bądź w procentach PKB),

- deficyt strukturalny, będący wielkością hipotetyczną, istniejącą w warunkach pełnego wykorzystania czynników wytwórczych, w tym pracy (pełnego zatrudnienia, pełnego wykorzystania mocy produkcyjnych) itp.,

- deficyt cykliczny, będący skutkiem zróżnicowanego stopnia wykorzystania zdolności wytwórczych w poszczególnych fazach cyklu koniunkturalnego, np. w kryzysie czy recesji; w ujęciu ilościowym stanowi on różnicę pomiędzy deficytem rzeczywistym a deficytem strukturalnym i wskazuje na to, jaka część deficytu rzeczywistego wynika z przyczyn koniunkturalnych.

Unia Europejska w traktacie z Maastricht oraz w Pakcie Stabilności i Wzrostu ratyfikowanym na szczycie w Amsterdamie w czerwcu 1997 roku zobowiązała kraje członkowskie do utrzymania dyscypliny fiskalnej i ograniczenia deficytu budżetowego do poziomu nieprzekraczającego 3\% PKB (Marchewka-Bartkowiak, 2011).

W sytuacji przekroczenia deficytu budżetowego w wysokości 3\% PKB w danym kraju członkowskim zostaje wszczęta na szczeblu UE procedura nadmiernego deficytu budżetowego. Polega ona przede wszystkim na (Kowalewski, 2001: 83-87):

- uchwaleniu rekomendacji w formie aktu bezpośredniego i bezwzględnie obowiązującego państwo członkowskie naruszające kryterium budżetowe,

- udzieleniu krajowi naruszającemu dyscyplinę budżetową tzw. noty upominającej, zawierającej wezwanie do podjęcia konkretnych działań,

- podjęciu decyzji o pomocy publicznej w formie transferu środków na rzecz kraju borykającego się z problemami budżetowymi; decyzja o takiej pomocy musi być podjęta przez Radę Unii Europejskiej i kwalifikowana większością głosów,

- nałożeniu sankcji w formie obowiązku złożenia depozytu stabilizacyjnego przez kraj; jeżeli przekroczenie ma charakter przejściowy, jest blisko progu 3\% PKB lub jest wynikiem pogorszenia się koniunktury gospodarczej, to wówczas nie wszczyna się procedury nadmiernego deficytu; w Polsce procedury ostrożnościowe i sanacyjne, zgodne ze standardami unijnymi, określa ustawa o finansach publicznych z dnia 27 sierpnia 2009 roku. 
W związku z tym, iż w Polsce w 2009 roku deficyt finansów rządowych i samorządowych wyniósł 7,1\% PKB, co stanowiło wzrost o 3,4\% w stosunku do 2008 roku, istotnie przekraczając próg 3\% PKB, 13 maja 2009 roku Komisja Europejska objęła Polskę procedurą nadmiernego deficytu (Strategia ..., 2010: 22). W 2013 roku deficyt budżetowy zmniejszył się i wyniósł 99,7 mld zł, czyli 4,7\% PKB, wykazując tendencję spadkową w kolejnych miesiącach. W związku z tym 3 czerwca 2014 roku w stosunku do Polski zawieszono procedurę nadmiernego deficytu budżetowego. Eliminacja nadmiernego deficytu nie kończy bowiem wyzwań związanych z zapewnieniem stabilności finansowej w Polsce. Komisja Europejska zastrzegła, że konieczna jest dalsza obserwacja sytuacji budżetowej w Polsce. „Trwała korekta nadmiernego deficytu w wyznaczonym terminie jest jednak obarczona ryzykiem”. Oznacza to, że na zamknięcie procedury nadmiernego deficytu wobec Polski trzeba trochę poczekać; zdaniem wielu ekonomistów nastąpi to jeszcze w 2015 roku (Procedura ..., 2014).

\section{Deficyt BudŻETOWy A DŁUG PUBLICZNY}

Deficyt budżetowy powoduje różnorodne skutki. Zależą one od jego wielkości, struktury, wykorzystanych instrumentów do jego finansowania oraz sytuacji ekonomicznej kraju. Do najważniejszych z nich zaliczyć należy przede wszystkim:

- absorpcję prywatnych oszczędności z rynku finansowego na potrzeby sektora publicznego; część oszczędności, które powstają w sektorze prywatnych przedsiębiorstw oraz gospodarstw domowych, zostaje przejęta (dobrowolnie) przez sektor publiczny, co wiąże się z ograniczeniem możliwości finansowania nowych inwestycji prywatnych, mających znaczenie dla dalszego wzrostu gospodarczego,

- wypieranie przez podmioty publiczne prywatnych pożyczkobiorców z rynków finansowych, co jest skutkiem podwyższania stopy procentowej i wyższego oprocentowania publicznych papierów wartościowych.

Najważniejszą konsekwencją deficytu budżetowego jest systematyczny wzrost długu publicznego oraz kosztów jego obsługi (Pach, 2013: 26-31).

Dług publiczny najczęściej definiowany jest jako „całość zobowiązań finansowych władz publicznych (państwowych i samorządowych) z tytułu zaciągniętych pożyczek" (Owsiak, 2013: 330). Jest on skutkiem zobowiązań państwa (władz publicznych) powstałych w wyniku:

- zaciągnięcia bezpośrednich pożyczek oraz kredytów, przeznaczonych przede wszystkim na finansowanie deficytów budżetowych,

- emisji papierów wartościowych, będących instrumentem zaciągania pożyczek pieniężnych,

- nieuregulowania przez jednostki sektora publicznego zobowiązań.

Dług publiczny wzrasta o tyle, ile w danym roku wynosi deficyt. Państwo zmuszone jest do wypłacania należnych odsetek z bieżących dochodów, zatem dług wpływa na powiększenie deficytu, a ten z kolei na zwiększanie się długu, co przedstawia ryc. 1. 
Ryc. 1. Zależność pomiędzy deficytem a długiem publicznym
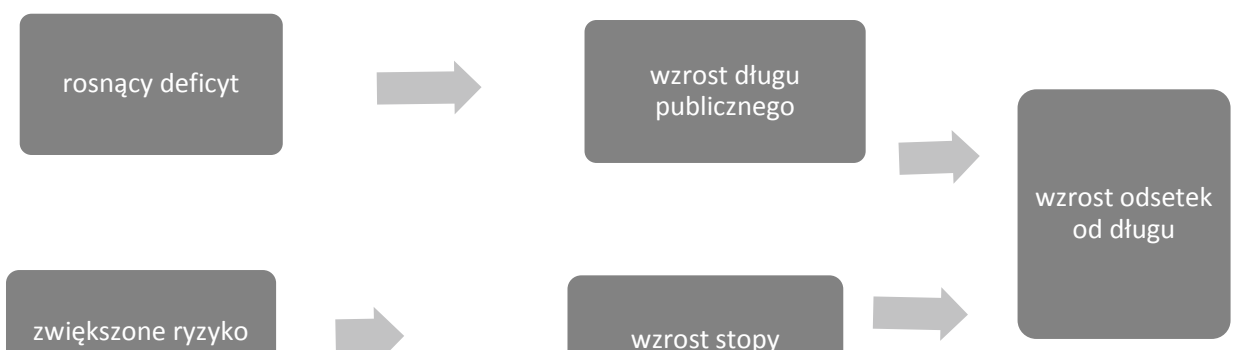

zwiększone ryzyko

udzielania pożyczek
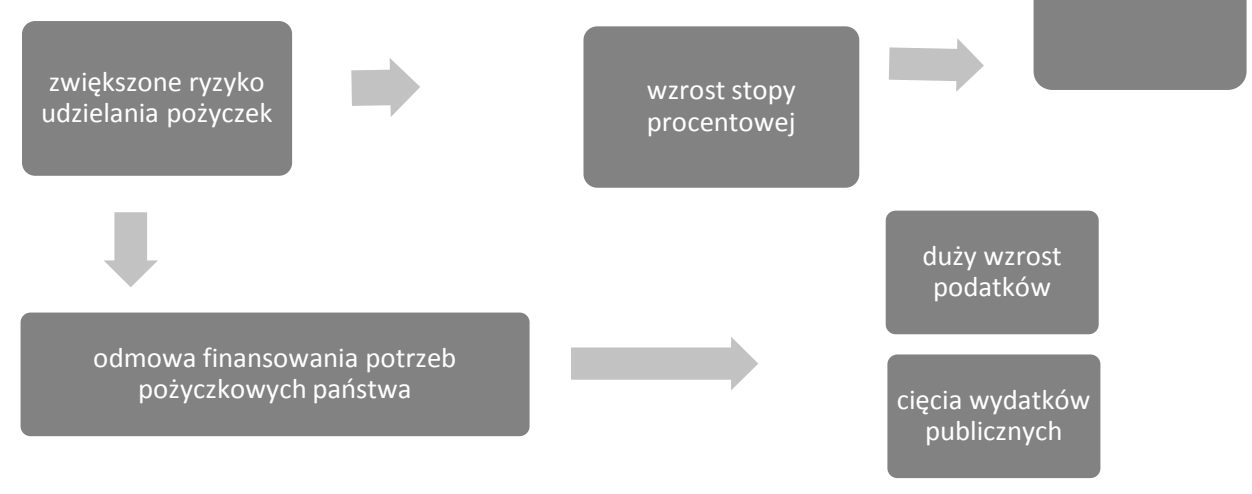

Źródło: Próchnicki (2012: 178)

Należy podkreślić, iż z długiem publicznym związane jest:

- ryzyko rynkowe określane jako zmiana kosztów obsługi zadłużenia wywołana zmianą stóp procentowych, kursu walutowego oraz stopy inflacji,

- ryzyko refinansowania wynikające z konieczności ponownego pokrycia potrzeb pożyczkowych rządu, emisji kolejnych transz papierów wartościowych - w celu wykupu wcześniej wyemitowanych papierów wartościowych,

- ryzyko kredytowe wynikające z zarządzania płynnością i należnościami budżetu państwa oraz z konieczności dalszego zaciągania kredytów,

- ryzyko płynności; chodzi o zachowanie zdolności do obsługi bieżących zobowiązań oraz zapewnienie płynności różnych segmentów wtórnego rynku instrumentów skarbowych.

Ponadto konsekwencją długu publicznego może być wzrost podatków obciążających społeczeństwo, przekładających się na przedsiębiorczość lokalną i krajową, jak również możliwość cięć wydatków publicznych. Wydatki te związane są w dużej mierze z pełnieniem przez państwo:

- klasycznych funkcji z zakresu bezpieczeństwa, ładu, porządku, administracji, sądownictwa,

- funkcji oświatowo-edukacyjnych,

- funkcji zdrowotnych i socjalnych,

- funkcji ekonomicznych, stymulujących wzrost i rozwój gospodarczy.

W Polsce wielkość długu publicznego regulowana jest takimi aktami prawnymi, jak: Konstytucja RP, ustawa o finansach publicznych, Traktat o funkcjonowaniu Unii Europejskiej, Pakt Stabilności i Wzrostu oraz innymi (por. tab. 1). 
Tab. 1. Regulacje wielkości długu publicznego

\section{Konstytucja RP}

- nie wolno zaciągać pożyczek lub udzielać gwarancji i poręczeń finansowych, w następstwie których państwowy dług publiczny przekroczy $3 / 5$ wartości rocznego PKB (art. 216, ust. 5)

\section{Traktat o funkcjonowaniu Unii Europejskiej}

- poziom długu publicznego, obok ograniczeń dotyczących deficytu, stanowi kryterium, w oparciu o które Komisja bada przestrzeganie dyscypliny budżetowej w państwach członkowskich (art. 126)

\section{Ustawa o finansach publicznych z dnia 27 sierpnia $2009 \mathrm{r}$.}

- jeśli relacja długu publicznego do PKB jest większa od 50\%, ale nie większa od 55\% PKB, to wówczas relacja deficytu budżetu państwa do PKB na rok $\mathrm{x}+2$ nie może być wyższa niż $\mathrm{w}$ roku $\mathrm{x}+1$

- jeśli relacja w roku x jest większa od 55\%, a mniejsza od $60 \%$, przyjmuje się wówczas szereg rozwiązań dotyczących kształtowania deficytu zarówno budżetu państwa, jak i budżetu jednostek samorządu terytorialnego, m.in. brak deficytu budżetu państwa lub taki jego poziom na rok $x+2$, który zapewni spadek relacji długu publicznego do PKB w stosunku do relacji ogłoszonej dla roku $\mathrm{x}$

- w uchwalonym budżecie nie przewiduje się wzrostu wynagrodzeń sfery budżetowej

- waloryzacja rent i emerytur nie może przekroczyć stopy inflacji w roku $\mathrm{x}+1$

- jeśli relacja dlugu publicznego w roku $x$ jest równa lub większa od $60 \%$ PKB, to obowiązują procedury dotyczące sytuacji, gdy dług jest większy niż 55\% PKB, a oprócz tego:

- wprowadzony jest zakaz udzielania nowych poręczeń i gwarancji przez podmioty sektora publicznego

- Rada Ministrów przedstawia Sejmowi program sanacyjny mający na celu ograniczenie państwowego długu publicznego do poziomu $60 \%$ PKB

- wprowadza się limity zaciągania zobowiązań przez jednostki samorządu terytorialnego (JST)

Źródło: opracowanie własne na podstawie: ustawy o finansach publicznych z dnia 27 sierpnia 2009 r., Strategii zarzadzania... (2010: 45-46) oraz Strategii zarządzania ... (2012: 20)

Sejm RP 26 lipca 2013 r. uchwalił nowelizację ustawy o finansach publicznych, która zawiesza pierwszy próg ostrożnościowy długu publicznego oraz przewiduje wstrzymanie sankcji nakładanych na finanse publiczne po jego przekroczeniu, tzn. gdy relacja długu publicznego do PKB przekracza 50\% (ryc. 2).

W związku z tą nowelizacją w sytuacjach uzasadnionych można zwiększać deficyt budżetowy $\mathrm{w}$ danym roku $\mathrm{w}$ relacji do roku poprzedniego (co wcześniej obwarowane było sankcjami). Powyższe regulacje prawne wpływały na wielkość długu publicznego w Polsce w ujęciu bezwzględnym i względnym (w stosunku do PKB), a tym samym na wielkość potrzeb pożyczkowych netto kraju (por. tab. 2.)

W całym analizowanym okresie dług publiczny wzrastał - w mld zł oraz w relacji do PKB, z wyjątkiem 2012 roku, w którym obowiązywała procedura nadmiernego deficytu budżetowego.

Ze względu na to, iż przed 2004 rokiem dług Polski wynosił poniżej 40\% PKB, obecnie sytuacja kraju na tle państw, które wraz z Polską lub później wstąpiły do UE, nie jest 
najgorsza (por. ryc. 3). Większy dług publiczny w relacji do PKB mają tylko Węgry, które w 2008 roku były zmuszone zwrócić się o pomoc do Międzynarodowego Funduszu Walutowego oraz Komisji Europejskiej. Obecnie narasta obawa o sytuację Słowenii, której dług publiczny jest tylko nieznacznie mniejszy od polskiego (por. ryc. 3). Natomiast w stosunku do średniej unijnej dziewięciu krajów polski dług jest znacznie wyższy.

Ryc. 2. Zasadnicze progi długu publicznego w Polsce

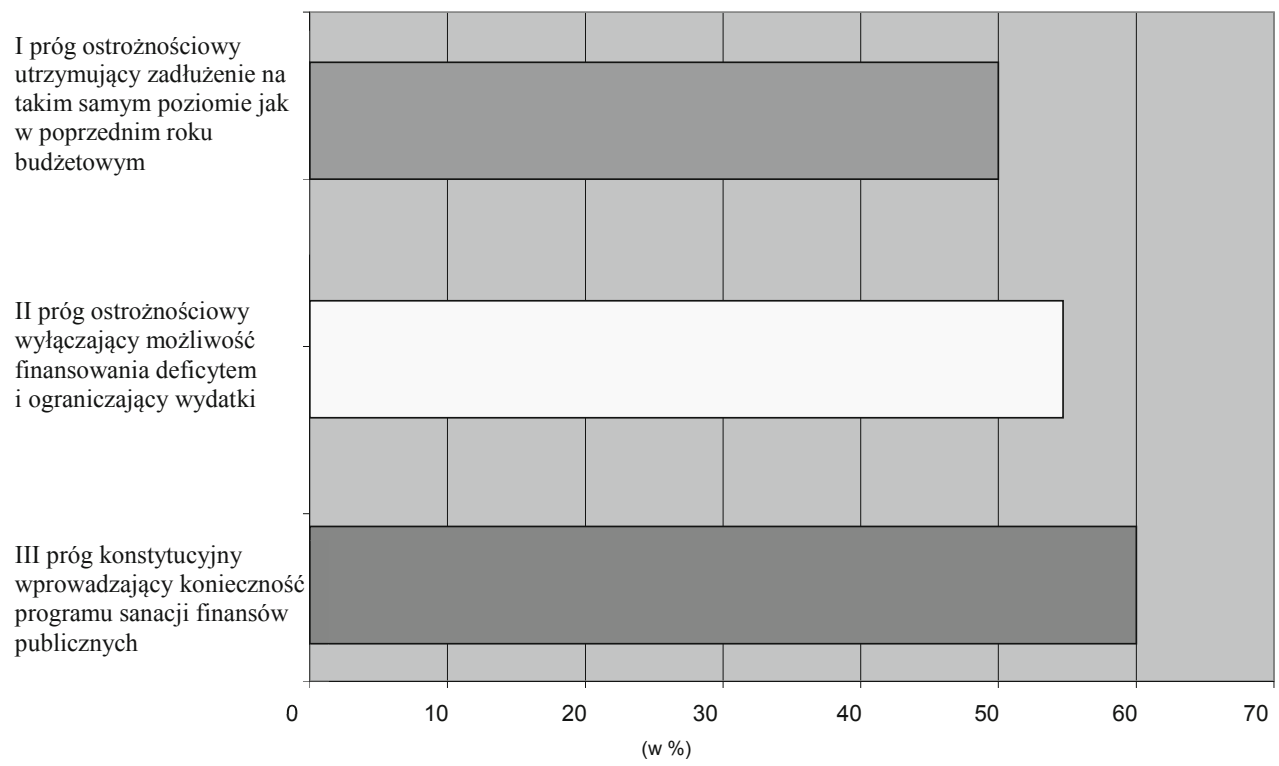

Źródło: opracowanie własne

Tab. 2. Wielkość i struktura długu publicznego w Polsce

\begin{tabular}{|l|c|c|c|c|c|c|c|c|}
\hline \multirow{2}{*}{ Wyszczególnienie } & \multicolumn{2}{|c|}{2010} & \multicolumn{2}{c|}{2011} & \multicolumn{2}{c|}{2012} & \multicolumn{2}{c|}{2013} \\
\cline { 2 - 9 } & w mld zf & $\%$ PKB & w mld zf & $\%$ PKB & w mld zl & $\%$ PKB & w mld zł & $\%$ PKB \\
\hline $\begin{array}{l}\text { Państwowy dług } \\
\text { publiczny }\end{array}$ & 747,9 & 52,8 & 815,3 & 53,4 & 840,5 & 52,7 & 880,2 & 53,9 \\
\hline $\begin{array}{l}\text { Dług publiczny } \\
\text { instytucji rządowych } \\
\text { i samorządowych }\end{array}$ & 776,8 & 54,8 & 859,1 & 56,2 & 858,9 & 55,6 & 926,8 & 55,9 \\
\hline
\end{tabular}

Źródło: opracowanie własne na podstawie Analiza... (2014, 30 kwietnia) oraz danych Ministerstwa Finansów 
Ryc. 3. Dług publiczny Polski na tle krajów Unii Europejskiej
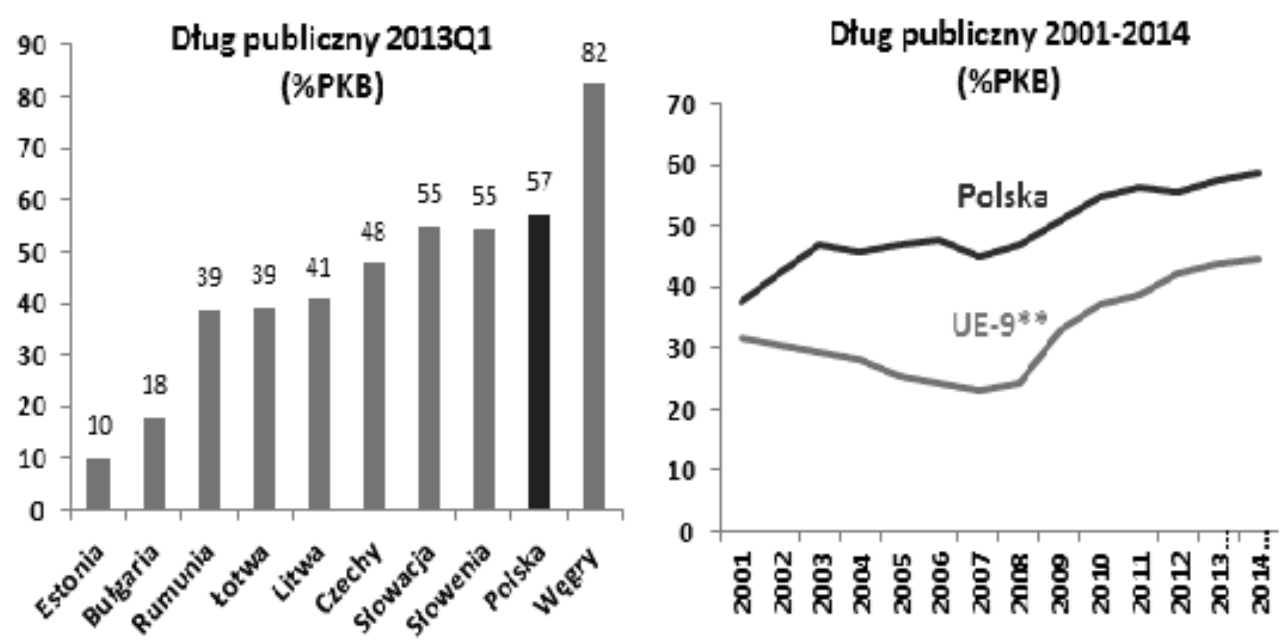

* Średnia dla Bułgarii, Czech, Estonii, Litwy, Łotwy, Rumunii, Słowacji, Słowenii i Węgier.

** Szacunki KE z maja 2013 roku.

Źródło: Polski dług... (2014, 30 czerwca)

Oprócz jawnego długu publicznego, mającego formę zaciągniętych przez państwo zobowiązań finansowych wobec osób prywatnych i rozmaitych instytucji (krajowych i zagranicznych), na państwach i społeczeństwach spoczywa także ukryty dług publiczny, czyli ustawowe zobowiązania państwa co do przyszłych wydatków. Szacunki Forum Obywatelskiego Rozwoju pokazują, iż ukryty dług stanowi 193\% PKB, czyli ponad 3 bln zł, co w przeliczeniu na mieszkańca daje ponad 83 tys. zł (Łaszek, 2014). Szczególną rolę dla bezpieczeństwa ekonomicznego odgrywa wyodrębnione bezpieczeństwo finansowe, definiowane najogólniej jako zdolność do pozyskania środków pieniężnych w sytuacji, gdy zachodzi taka potrzeba (Neil, 2010).

Z przeprowadzonych powyżej rozważań wynika, iż dług publiczny jest problemem gospodarczym realnie występującym w Polsce, wymagającym właściwego zarządzania. Zarządzaniu długiem towarzyszy szereg ryzyk (omówionych wcześniej) oraz niepewności nie zawsze do końca zidentyfikowanych (Draft guidelines..., 2000). Głównym celem zarządzania jest zapewnienie danemu krajowi dostępu do środków finansowych oraz optymalnej struktury zadłużenia państwa pod względem wielkości, struktury, stosowanych instrumentów finansowych (określenie ich waluty, oprocentowania, terminu wykupu itp.).

Cel szczegółowy jest określany na konkretny okres. Na lata 2014-2017 celem Strategii zarządzania długiem ... pozostanie minimalizacja kosztów obsługi długu w długim horyzoncie czasu przy przyjętych ograniczeniach dotyczących poziomu ryzyka (Strategia zarządzania..., 2013: 32): refinansowego, kursowego, stopy procentowej, płynności finansowej budżetu, kredytowo-operacyjnego. 
Cel ten jest rozumiany w dwóch aspektach:

1. odpowiedniego doboru instrumentów, czyli pod względem terminu wykupu instrumentów (o jak najdłuższym okresie) i ich istotnym udziale w finansowaniu długu, optymalnego doboru rynków i struktury finansowania potrzeb pożyczkowych i terminów emisji nowych papierów wartościowych;

2. zwiększania efektywności rynku skarbowych papierów wartościowych (SPW).

Realizacja celu minimalizacji kosztów obsługi długu wymaga elastycznego kształtowania struktury finansowania pod względem wyboru rynku, waluty oraz typu instrumentów dłużnych. Wybór struktury finansowania powinien być rezultatem oceny sytuacji rynkowej (poziomu stóp procentowych i kształtu krzywej dochodowości na poszczególnych rynkach oraz oczekiwanych poziomów kursów walutowych) i wynikać z porównania kosztów pozyskiwania środków w długim horyzoncie czasowym.

Doświadczenia zarządzania długiem wskazują na znaczenie elastyczności i dywersyfikacji źródeł finansowania potrzeb pożyczkowych - zarówno środków krajowych, jak i zagranicznych.

\section{Podsumowanie}

Dług publiczny jest poważnym problemem gospodarczym wielu krajów na świecie, w tym również niektórych krajów Unii Europejskiej. Oddziałuje on na wielkość inwestycji (prywatnych i publicznych), konsumpcję, wzrost gospodarczy oraz implikuje szereg procesów gospodarczych. Dlatego istotne jest nieprzekraczanie jego ustawowych progów, stosowanie procedur ostrożnościowych, ocena ryzyka zadłużeniowego oraz właściwe zarządzanie długiem publicznym. Chodzi o to, aby dług publiczny był narzędziem finansowania rozwoju gospodarczego, niezbędnych zmian w zakresie struktury gospodarczej, a nie jego barierą lub czynnikiem naruszającym bezpieczeństwo finansowe kraju.

Ze szczególną ostrością pokazał to ostatni kryzys gospodarczy, który w Unii Europejskiej związany był z nadmiernym długiem publicznym oraz nieprzestrzeganiem dyscypliny finansowej w takich krajach, jak: Grecja, Włochy, Hiszpania, Irlandia. Niektóre z nich (te o największym zadłużeniu) miały poważne problemy z pozyskaniem nowych kredytów i utrzymaniem płynności budżetowej. Natomiast pomoc oferowana przez Unię Europejską, Bank Światowy, Międzynarodowy Fundusz Walutowy uwarunkowana była podjęciem przez te instytucje szeregu reform mających na celu racjonalizację wydatków budżetowych. Ze względu na koszty społeczne były one trudne do zaakceptowania i nierzadko wiązały się z protestami i niezadowoleniem społecznym obywateli. Wszystkie programy naprawcze finansów publicznych budzą wiele emocji, opór społeczny, gdyż ich konsekwencje najsilniej dotykają najmniej zamożnych grup społecznych, ludzi młodych, wchodzących na rynek pracy. Oddłużenie i restrukturyzacja zadłużenia to proces długi, kosztowny, wymagający przyzwolenia społeczno-politycznego.

W Polsce skala i skutki długu publicznego były mniejsze niż w innych krajach Unii Europejskiej. Wynika to z faktu mniejszego długu publicznego w relacji do PKB, wynoszącego poniżej $60 \%$ PKB, niższych kosztów jego obsługi oraz wyższego tempa wzrostu 
gospodarczego. Niemniej jednak niepokojące są „uporczywe i powtarzające się” deficyty skutkujące wzrostem zadłużenia publicznego. Wydaje się, iż nałożona na Polskę przez Unię Europejską procedura nadmiernego deficytu budżetowego (zawieszona w 2013 roku, ale niezamknięta) skutkować będzie w kolejnych latach dyscypliną budżetową i kształtowaniem deficytu budżetowego na poziomie niższym niż 3\% PKB. Jest to główny warunek utrzymania długu publicznego na bezpiecznym poziomie, niepowodującym negatywnych konsekwencji gospodarczych.

\section{Literatura \\ References}

Analiza wykonania budżetu (2014, 30 kwietnia). Pozyskano z http:// www.nik.gov.pl/aktualnosci/przemowienie-prezesa-nik-analiza-wykonania-budzetu.html.

Bertalanffy, L. (1984). Ogólna teoria systemów. Podstawy, rozwój, zastosowania. Warszawa: PWN.

Dalton, H. (1948). Zasady skarbowości. Łódź: Wydawnictwo Kazimierza Rutskiego.

Dlug publiczny w Polsce rośnie (2014). Pozyskano z http://www.finanse.egospodarka.pl/47524.

Draft guidelines for public debet managment (2000). IFT and the World Bank.

Kell, M. (2001). An assessment of fiscal rules in the United Kingdom. IMF Working Paper, 91.

Kowalewski, P. (2001). Euro a międzynarodowy system walutowy, Warszawa: Twigger.

Łaszek, A. (2014). Ukryty dlug na liczniku długu publicznego. Forum Obywatelskiego Rozwoju.

Marchewka-Bartkowiak, K. (2011). Stability and Growth Pact, Infos, 11.

Neil, M. (2010). Financial Future. Personal Excellence, 5.

Owsiak, S. (2013). Finanse publiczne. Teoria i praktyka. Warszawa: PWN.

Pach, J. (2013). Problem długu publicznego w kontekście bezpieczeństwa finansowego Polski. W: Bezpieczeństwo RP. Historia-Ekonomia-Polityka. Kraków: Wydawnictwo Naukowe Uniwersytetu Pedagogicznego.

Polski dlug publiczny na tle państw regionu (2014, 30 czerwca). Pozyskano z http://www.dlugpubliczny.org.pl/pl/metoda-liczenia.

Procedura nadmiernego deficytu wobec Polski zawieszona (2014, 20 listopada). Pozyskano z http:// www.euractiv.pl/gospodarka/artykul/procedura-nadmiernego-deficytu-wobec-polski-zawieszona

Próchnicki, L. (2012). Rola deficytu budżetowego w gospodarce - ewolucja teorii. Studia i Prace Wydziału Nauk Ekonomicznych i Zarzadzania, 27. Szczecin: Uniwersytet Szczeciński.

Standard Bank: rubel załamat się, bo gospodarka niezdywersyfikowana (2014, 17 grudnia). Pozyskano z http://biznes.onet.pl/wiadomosci/swiat/standard-bank-rubel-zalamal-sie-bo-gospodarka-niezdywersyfikowana/95bj81.

Strategia zarządzania dlugiem sektora finansów publicznych w latach 2011-2014 (2010). Warszawa: Ministerstwo Finansów.

Strategia zarządzania dlugiem sektora finansów publicznych w latach 2013-2016 (2012). Warszawa: Ministerstwo Finansów.

Strategia zarządzania dlugiem sektora finansów publicznych w latach 2014-2017 (2013). Warszawa: Ministerstwo Finansów.

Ustawa o finansach publicznych z dnia 27 sierpnia 2009 r. (Dz.U. z 2009 r. nr 157, poz. 1240).

Janina Pach, doktor habilitowany nauk ekonomicznych, profesor nadzwyczajny, kierownik Katedry Ekonomii i Polityki Gospodarczej na Uniwersytecie Pedagogicznym w Krakowie. Autorka licznych artykułów naukowych z dziedziny ekonomii, międzynarodowych stosunków gospodarczych, finansów publicznych i polityki gospodarczej, rozdziałów w książkach i książek. Dorobek naukowy ogniskuje się przede wszystkim wokół:

- międzynarodowych przepływów myśli naukowo-technicznej, 
- międzynarodowych przepływów kapitałowych, w tym bezpośrednich inwestycji zagranicznych i kredytów zagranicznych,

- różnych aspektów funkcjonowania małych i średnich przedsiębiorstw,

- finansów państwa, ze szczególnym uwzględnieniem polityki budżetowej.

Janina Pach, Associate Professor of Economic Sciences, Head of Department of Economics and Economic Policy of Pedagogical University of Cracow. Author of numerous scientific articles in the field of economics, international economic relations, public finance and economic policy, chapters in books, and books. Scientific achievements focus mainly on:

- international flow of scientific and technical solution,

- international capital flow, including foreign direct investments and foreign loans,

- various aspects of the functioning of small and medium enterprises,

- public finance, with special emphasis on fiscal policy.

\section{Adres/address:}

Uniwersytet Pedagogiczny w Krakowie

Instytut Politologii

Katedra Ekonomii i Polityki Gospodarczej

ul. Podchorążych 2, 30-084 Kraków, Polska

e-mail: janina.pach@poczta.onet.pl 